\title{
Research Article \\ Effect of Turf Roof Slabs on Indoor Thermal Performance in Tropical Climates: A Life Cycle Cost Approach
}

\author{
R. U. Halwatura \\ Department of Civil Engineering, University of Moratuwa, Moratuwa 10400, Sri Lanka \\ Correspondence should be addressed to R. U. Halwatura; rangikauh@gmail.com
}

Received 30 March 2013; Accepted 19 September 2013

Academic Editor: Khandaker Hossain

Copyright (C) 2013 R. U. Halwatura. This is an open access article distributed under the Creative Commons Attribution License, which permits unrestricted use, distribution, and reproduction in any medium, provided the original work is properly cited.

\begin{abstract}
Urbanization related to population growth is one of the burning issues that the world is facing today. Parallel to this, there is visible evidence of a possible energy crisis in the near future. Thus, scientists have paid attention to sustainable development methods, and in the field of building construction also, several innovations have been proposed. For example, green roof concept is one of such which is considered a viable method mainly to reduce urban heat island effect, to regain lost land spaces in cities, and to increase aesthetics in cities. The present study was aimed at investigating the impact of green roofs on indoor temperature of buildings, the effect of different types of roofs on the air conditioning loads, and the life cycle cost of buildings with different types of roofing. The study was conducted in several phases: initial small-scale models to determine the heat flow characteristics of roof top soil layers with different thicknesses, a large-scale model applying the findings of the small-scale models to determine temperature fluctuations within a building with other common roofing systems, a computer simulation to investigate air conditioning loads in a typical building with cement fiber sheets and green roof slabs, a comparative analysis of the effect of traditional type roofs and green roofs on the air conditioning loads, and finally an analysis to predict the influence of traditional type roofs and green roofs on life cycle cost of the buildings. The main findings of the study were that green roofs are able to reduce the indoor temperature of buildings and are able to achieve better heat transfer through the roof, and, thus a lower cooling load is necessary for air conditioning and has the possibility of reducing life cycle cost of a building.
\end{abstract}

\section{Introduction}

In the past few decades, scientists have focused greater attention on sustainable development because of the energy crisis which has reached up to an alarming level by now. Energy requirement of urbanized areas is rising rapidly $[1,2]$. Since people are becoming much concerned about thermal comfort, the demand for energy has also been at a rise. However, this could lead to an energy crisis with the expected global climatic changes [3]. Moreover, higher consumption of energy may result in urban heat island effect in cities [3]. As the development of cities is coupled with environmental pollution, primarily in the developing countries, environmental friendly constructions are essential [1]. Further to this, the impact of developmental activities on environment forces us to implement sustainable development methods [1].

As a result, the traditional construction methods are being replaced with new innovations, and the new trends highlight that the traditional sloping roofs are being replaced by flat slabs, since they can create another usable space at the roof level [3-5]. These spaces can also be utilized to create green environment at the roof level. Buildings containing greenery would be a possible solution for many environmental and social issues, such as rising air temperature and losing green land spaces, faced by occupants in urban areas [6]. Growing grass is identified to be one of the most effective ways of achieving greenery over roof slabs in these areas providing additional benefits such as reduction of indoor temperature [7].

The present study, carried out in several phases, was mainly aimed at investigating the impact of growing grass on roof tops on indoor temperature of buildings, the effect of different roofs on the air conditioning loads necessary to reduce temperature, and the life cycle cost values of buildings with different types of roofing. This paper presents the theoretical background to the study, the methodology adapted, and the results. It also discusses the findings under 
each phase of the study and summarizes the main findings in the conclusion.

\section{Theoretical Background to the Study}

The rapid urbanization of the world's population over the twentieth century is described in the 2011 Revision of the UN World Urbanization Prospects report. The global urban population rose dramatically from 0.73 billion in 1950 to 1.51 billion in 1975 with an average annual rate of change of $2.91 \%$, and to 3.42 billion in 2009 with an average annual rate of change of $2.4 \%$ from 1975 to 2009 [8]. The same report projected that the figure is likely to rise to 6.3 billion in 2050 [8]. According to the UN State of the World Population 2007 report [9], in 2008, the majority of people worldwide migrated to towns or cities, for the first time in history; this is referred to as the arrival of the "Urban Millennium" or the "tipping point" [10]. With regard to future trends, it is estimated that $93 \%$ of urban growth will occur in developing nations with $80 \%$ of urban growth occurring in Asia and Africa [9].

This trend is already visible in Sri Lanka and as a result of rapid urbanization, the ownership of land per person is decreasing in most developing cities in the country with a rapid increase of the value of lands. This leads to buildings covering most of the land available [1] and most of the cities appeared to be concrete yards because people tend to regain flat open space, which they lost due to buildings, by using reinforced concrete roof slabs. Although this is a more desirable option than having a typical roof with a ceiling, it creates additional problems with respect to occupant thermal comfort and the urban heat island effect $[1,2]$. Urban heat island effect can cause serious damage to the environment and to humans by decreasing thermal comfort in the urban areas [3]. For example, the 1995 heat wave in Chicago caused the death of 739 people within a week [11].

Green roofs can decrease the urban heat island by a considerable magnitude by increasing vegetation and surface reflectivity [3-5]. It is reported that planted roofs contribute not only to reducing the thermal loads on the building but also to reducing urban heat island effects in densely built areas with little natural environment [3]. Rooftop vegetation has been investigated deeply in many countries and it has been identified as a viable option to solve many social and environmental issues [6]. It is revealed that the planted roofs can reduce the air temperature beneath the plants by 4 to $5^{\circ} \mathrm{C}$ [12]. It has been also realized that the rooftop temperature can be reduced by about $15^{\circ} \mathrm{C}$ depending on the vegetation cover, which reduces the transmittance of solar radiation up to $50 \%$ [13].

The sloping roofs are very common in many developing countries. Most developing countries are still using relatively low cost roofing materials such as cement fiber sheets and clay tiles [14]. However, uninsulated roofs cannot perform efficiently with respect to thermal comfort inside the building. The roof top surface temperature can reach 45 to $50^{\circ} \mathrm{C}$ with low absorptance. It can be as high as 60 to $70^{\circ} \mathrm{C}$ with high absorptance. Since most of the roof covering materials would have a thickness less than $15 \mathrm{~mm}$, the temperature of the inner surface also would have similar values [15]. The use of reinforced concrete roof slabs without insulation can also lead to several problems with respect to thermal comfort and serviceability of the structure. Since the slab is directly exposed to sunlight, a lot of heat can be absorbed by the slab and the heat would be transmitted inwards and hence the slab soffit can remain at a high temperature [3]. This would directly and greatly influence the indoor thermal comfort. Since the slab is connected to the other supporting members such as beams, columns, and masonry walls, some serviceability problems such as various forms of thermal cracks could also arise [16].

An authentic solution to this problem could be the use of a green roof slab. "Green roof" is the term given to a vegetated space that is structurally integrated on top of a man-made structure [7]. A roof garden reestablishes the relationship between man and nature that can be lost in urban environments [17]. Rooftop gardens also help to enhance the aesthetics of the cities and may create healthy cities. When introducing alternatives such as green roof slabs instead of traditional roof arrangements, it is necessary to carry out a life cycle cost analysis as well. In the face of rising energy costs and the global warming potential associated with energy generation, it is useful to pay attention to both initial capital cost and the running cost while appreciating the benefits that can be offered by alternative solutions [3]. A detailed study to find out the effect of green roof slabs on the air conditioning loads will also be very useful. It may help to identify the real benefits given to a building by a green roof slab with an optimum soil thickness rather than air conditioning to gain better indoor thermal comfort.

This theoretical background related to the green roof concept paved the way to design a study that investigated the effects of green roof on indoor temperature, the energy demand for air conditioning, and the life cost of a building. The study was conducted in Sri Lanka, which is a tropical country that requires sustainable development models to mitigate environmental issues related to urbanization.

\section{Methodology}

The following approach was used to achieve the study aims.

(a) Actual small-scale models with green roof slabs having soil thicknesses of 25,50 , and $75 \mathrm{~mm}$, respectively, were designed and the temperature in those models was measured separately to find out the heat flow characteristics.

(b) Based on the results of the small-scale study, a largescale model was created in a three-story building and the temperature within the large-scale real building was recorded.

(c) Computer simulation was carried out to investigate the predicted temperature and the air conditioning loads in a typical building with cement fiber sheets and green roof slabs.

(d) A comparative study was carried out using the above simulation results for traditional roofs and green 


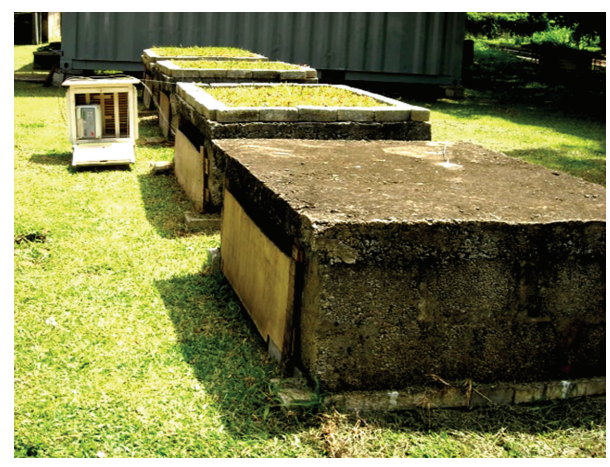

FIGURE 1: Four models used for the small-scale investigation.

roof slabs with different soil thicknesses to determine the effect of different roofs on the sensible heat component of the air conditioning loads.

(e) All these findings were used to predict the influence of different types of roofs on life cycle costs parameters.

These five different steps are discussed in detail in the following section.

\section{Implementation, Results, and Discussion}

\subsection{Small-Scale Models}

4.1.1. Design and Implementation. The initial investigation started with four small-scale models. The indoor comfort conditions were determined by measuring the indoor temperature and the slab soffit temperature. Each model consists of two walls with $125 \mathrm{~mm}$ cement block work on either side. The length and the height of each were $1.25 \mathrm{~m}$ and $0.5 \mathrm{~m}$, respectively. The other two sides were covered with plywood boards of $9 \mathrm{~mm}$ thickness. A space of $100 \mathrm{~mm}$ was provided for ventilation at the top. A $125 \mathrm{~mm}$ slab was used as the roof for all the models. Buffalo grass (Bouteloua dactyloides) was used for these models due to the fact that buffalo grass is considered the most suitable grass for tropical countries. Buffalo grass is perhaps a truly native turf grass [18]. Its tolerance to prolonged droughts and to extreme temperatures together with its seed producing characteristics enables buffalo grass to survive in extreme environmental conditions [18]. One model with only a concrete slab was kept as a spare model. In the other models, the slab was covered with a layer of soil. The soil selected was rich with sand than vegetable matter to ensure good drainage conditions on the model. Three soil thicknesses were considered after intensely studying the growing characteristics of grass and also with the help of the results obtained in initial field investigations. Figure 1 illustrates the models used for the temperature measurements.

The first model was kept without a grass cover (Case 1). The other models were given a grass cover with soil thickness of $25 \mathrm{~mm}$ (Case 2), $50 \mathrm{~mm}$ (Case 3), and $75 \mathrm{~mm}$ (Case 4), respectively. The slab soffit temperature and slab top temperature of each model were recorded for a period of 24 hours on a sunny day.

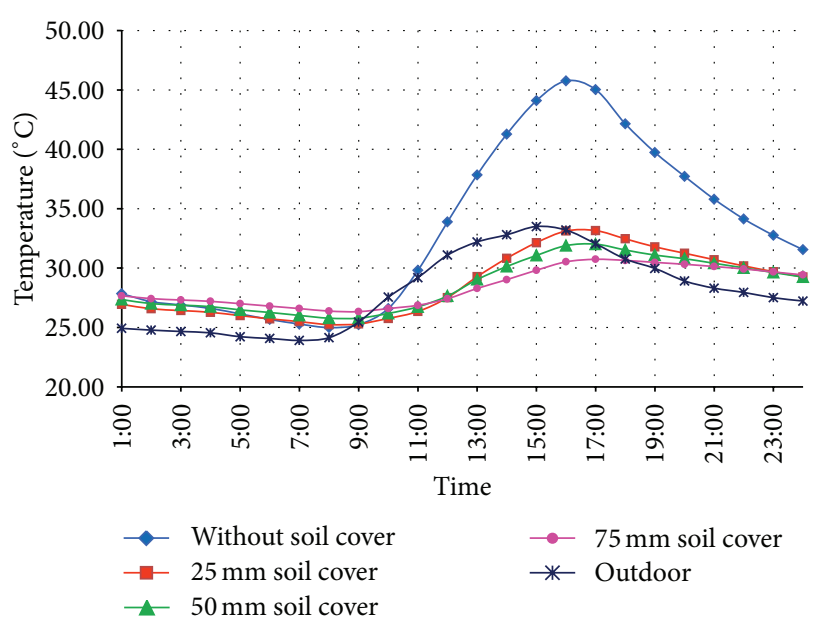

FIGURE 2: Slab soffit temperature distribution for different soil thicknesses.

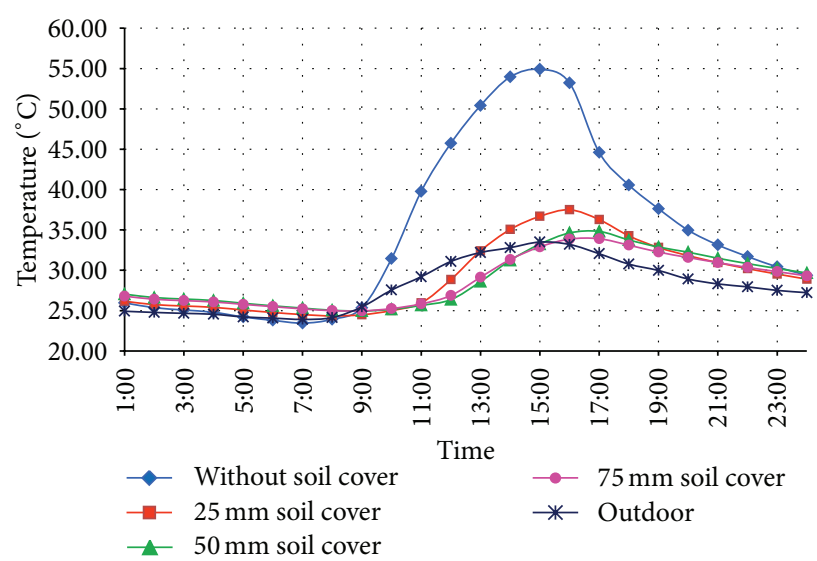

FIGURE 3: Surface (slab top) temperature distribution for different soil thicknesses.

4.1.2. Results. The slab soffit temperatures obtained are presented in Figure 2 for the following cases: without grass cover and with grass covers on $25 \mathrm{~mm}, 50 \mathrm{~mm}$, and $75 \mathrm{~mm}$ thickness of soil, respectively.

Figure 2 indicates the variation of the slab soffit temperature of the models for 24 hours. During day time, the maximum slab soffit temperature reached $45.7^{\circ} \mathrm{C}$ without soil cover, which indicates that it could emit considerable amount of long wave radiation during daytime. The maximum slab soffit temperatures of the models with $25 \mathrm{~mm}, 50 \mathrm{~mm}$, and $75 \mathrm{~mm}$ soil covers were $33.2,32.0$, and $30.7^{\circ} \mathrm{C}$, respectively. It is almost equal to the maximum ambient temperature of $33.5^{\circ} \mathrm{C}$. During night time, soffit temperature was approximately the same for all four cases. It varied between 25 and $28^{\circ} \mathrm{C}$, when the outdoor temperature remained below $25^{\circ} \mathrm{C}$. The model with $75 \mathrm{~mm}$ thick soil cover displayed a higher soffit temperature during night time compared to other cases.

Figure 3 illustrates the variation of the slab top temperature of the models for 24 hours. The maximum slab top temperature reached $54.9^{\circ} \mathrm{C}$ in the model without soil cover, 


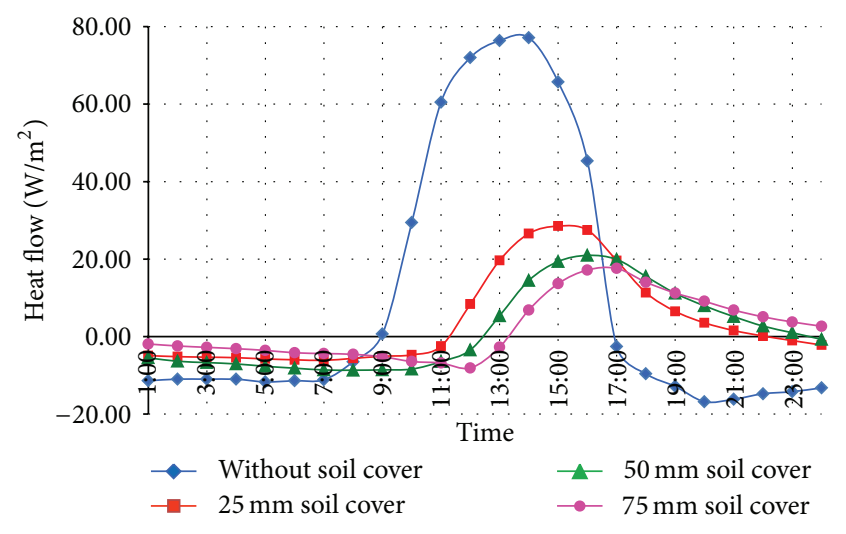

FIGURE 4: Heat flow values for different soil thicknesses.

which indicates that it could absorb considerable amount of short wave radiation during the day time because it was directly exposed to the sun. The maximum slab top temperatures of the models with $25 \mathrm{~mm}, 50 \mathrm{~mm}$, and $75 \mathrm{~mm}$ soil covers were $37.5,34.8$, and $33.9^{\circ} \mathrm{C}$ respectively. During night time, the slab top temperature was approximately the same for all four cases. The models with $75 \mathrm{~mm}$ and $50 \mathrm{~mm}$ thick soil covers demonstrated high night time temperatures compared to the other models. Further, the slab top temperatures of these two models roughly overlapped with each other throughout the day.

Slab top temperature and the temperature gradient over the thickness of the slab cause thermal expansion and thermal cracks on the supporting structure. Even with a $25 \mathrm{~mm}$ insulation layer and another $40 \mathrm{~mm}$ covering screed concrete layer above, the slab top temperature can go up to $35^{\circ} \mathrm{C}$. Hence, the performance of the model with a $50 \mathrm{~mm}$ soil layer can be compared to the performance of a slab with a proper $25 \mathrm{~mm}$ thick insulation system with respect to thermal expansion of the slab [19]. This indicates that a turf roof slab with a $50 \mathrm{~mm}$ soil layer can reduce the tendency for thermal cracks to appear on supporting structures.

The corresponding heat flow values could be determined by using " $U$ " values for the slab, the slab top surface, and soffit temperatures. The calculated " $U$ " value was $3.94 \mathrm{~W} / \mathrm{m}^{2} \mathrm{~K}$ for the slab without grass cover and $4.68 \mathrm{~W} / \mathrm{m}^{2} \mathrm{~K}$ for the models with grass cover. Since the slab top and soffit temperatures can be measured, the above " $U$ " value calculations were done only for the concrete slab to calculate the heat flow. A detailed calculation of $U$ values is presented in the appendix. Figure 4 indicates the heat flow values of the models with different soil thicknesses. Heat flow took place through the slab to the indoors from $9.00 \mathrm{am}$ to $5.00 \mathrm{pm}$. The maximum heat flow of the model without soil cover reached $77.1 \mathrm{~W} / \mathrm{m}^{2}$. The maximum heat flow obtained was $28.5 \mathrm{~W} / \mathrm{m}^{2}$ for $25 \mathrm{~mm}$, $20.9 \mathrm{~W} / \mathrm{m}^{2}$ for $50 \mathrm{~mm}$, and $17.6 \mathrm{~W} / \mathrm{m}^{2}$ for $75 \mathrm{~mm}$ thick soil cover models, respectively. This is a significant reduction of heat flow through the slab towards the occupants. There was one hour time difference between the peak heat flow values in the four cases. When compared to an insulated roof slab, these heat flow values are at a similar range and the performance

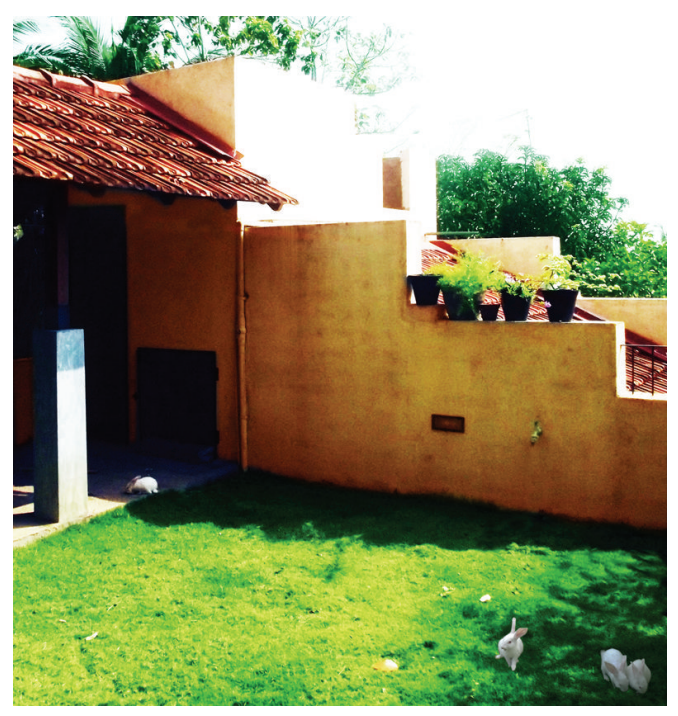

Figure 5: Turf roof with other roofing types.

can be easily matched to the performance of a system with a $25 \mathrm{~mm}$ insulation layer [19].

It was also noted that even the night time performance of a roof slab can be improved by introducing grass cover over the slab. An unprotected slab can start reversing the heat floor at around $5 \mathrm{pm}$ and it would continue transferring heat to outdoor until $9.00 \mathrm{am}$ in the morning. This can reach even about $17 \mathrm{~W} / \mathrm{m}^{2}$ at around $8.00 \mathrm{pm}$, while the heat flow of other models with grass cover was observed to remain approximately constant.

\subsection{Real-Scale Model}

4.2.1. Design and Implementation. Through the initial investigations, it was possible to identify that green roofs assist in reducing indoor temperature in buildings. There is also an influence of soil thickness in green roofs in enhancing the indoor temperatures in the upper floors of buildings; however, the effect is not significant. Furthermore, it was identified that the minimum sustainable soil thickness necessary for growing conditions was $50 \mathrm{~mm}$. This was taken into consideration and a real-scale model was created in a building where the other types of roof protections also existed. This was a three-story house with separate sections having different roofing arrangements. Figures 5 and 6 illustrate the roof plan and the house, which was used in the large-scale model.

Three locations were selected for the temperature measurements. They were a tile roof with a $1 / 2^{\prime \prime}$ timber ceiling, a bare concrete slab with $115 \mathrm{~mm}$ thickness, and a turf roof with a $115 \mathrm{~mm}$ concrete and $50 \mathrm{~mm}$ soil cover.

4.2.2. Results. The temperature measurements were taken on sunny days and the measurements for one day are presented in Figure 7. Three measurements at each location were taken for consecutive days. Apart from the outdoor temperature, 


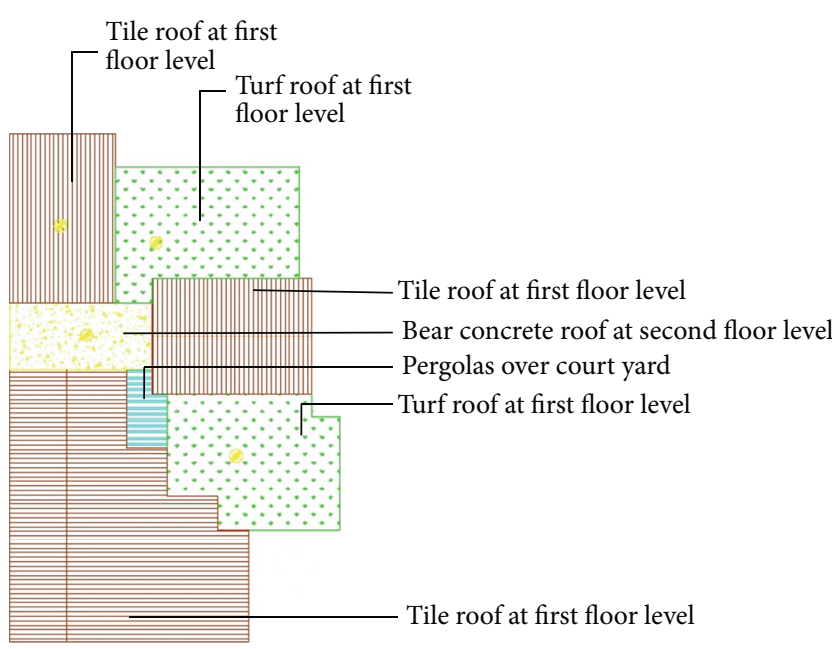

Locations of the measurements

Figure 6: Roof plan.

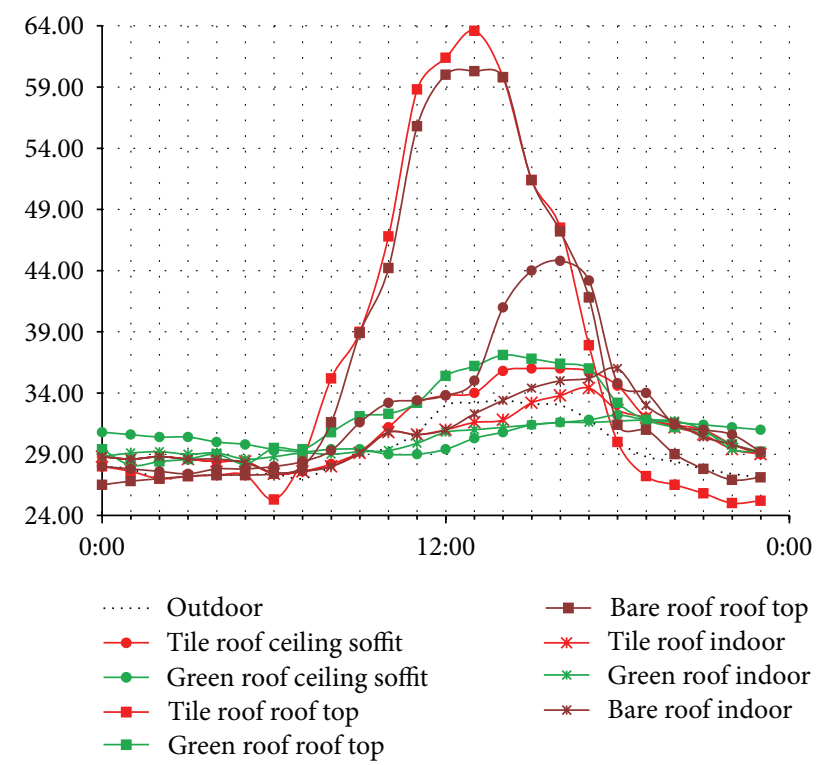

FIgURE 7: Temperature measurements for different roof coverings in the real building.

outdoor surface temperature, indoor surface temperature, and indoor volume temperature were measured at each location.

The highest indoor temperatures where there were tile roofs, bare roofs and green roofs, were $34.5^{\circ} \mathrm{C}, 35.9^{\circ} \mathrm{C}$, and $32.7^{\circ} \mathrm{C}$, respectively. The highest roof/slab soffit temperatures of these three roofing conditions were $36.4^{\circ} \mathrm{C}, 45^{\circ} \mathrm{C}$, and $32.6^{\circ} \mathrm{C}$, respectively. Both the minimum highest indoor room temperature and slab soffit temperature were recorded at places with turf roofs. Since the green roof recorded the minimum highest slab top temperature $37^{\circ} \mathrm{C}$ compared to the temperatures of the bare roof slab top $61^{\circ} \mathrm{C}$ and tile roof roof-top $63.6^{\circ} \mathrm{C}$, the heat gain in turf roof was at a minimum compared to the other two roofs.

\subsection{Computer Simulations}

4.3.1. Design. Both small-scale and real-scale studies highlighted that green roofs can be an effective technique for passive cooling of buildings; however, research on the stated area is still rare in bioclimatic studies. A major reason for this could be the difficulty of thermal simulation that follows such constructions. Several simulation models have been discussed in various researches [20] and computer simulations are one of such that can be used to predict the thermal performance inside the building created due to different types of roofing systems. Even though the computer simulations are not accurate since the actual conditions cannot be simulated in the computer model and also the exact representation of the actual behavior cannot be created, these can predict the trend with a fairly good accuracy. Thus, computer simulations can be used to do comparative studies by varying one factor while keeping others constant. DEROBLTH is versatile software, which is well-tested worldwide to perform computer simulations on thermal behavior of buildings. DEROB-LTH was calibrated using the temperature fluctuations within actual buildings with insulated roof slabs. The details of calibration can be found in Halwatura and Jayasinghe [13]. It has also been validated by many researchers [17-19]. In this study, computer simulations were used to calculate air conditioning loads which in turn assisted to calculate the life cycle cost for each case.

4.3.2. Models Used for Computer Simulation. A three-storied real scale building model was used for the simulation. The building was considered to be $15 \mathrm{~m} \times 15 \mathrm{~m}$ in the plan. Two roofing arrangements were initially chosen: a traditional sloping roof with an insulation layer and a green roof with different soil thicknesses. Those were included in the computer models due to the fact that, on one hand, this paper discusses the passive features affecting the temperature, and on the other hand, the research was aimed at investigating the performance of a turf roof as a passive technique and the models were created with all the possible passive techniques. The passive features that were included in the models are as follows:

(i) windows were located on southern and northern directions; therefore, the direct solar radiations can be blocked as much as possible;

(ii) shading screens were used to protect the windows;

(iii) $225 \mathrm{~mm}$ thick brick walls could reduce the heat transfer through the exposed walls [21];

(iv) in the sloping roof, a reflective insulation layer laminated to resistive insulation layer was used to reduce the heat transfer through the roof. This is very common in Sri Lanka [1].

Such passive features generally have the potential to reduce the indoor air temperature by about $3^{\circ} \mathrm{C}$ below the outdoor 


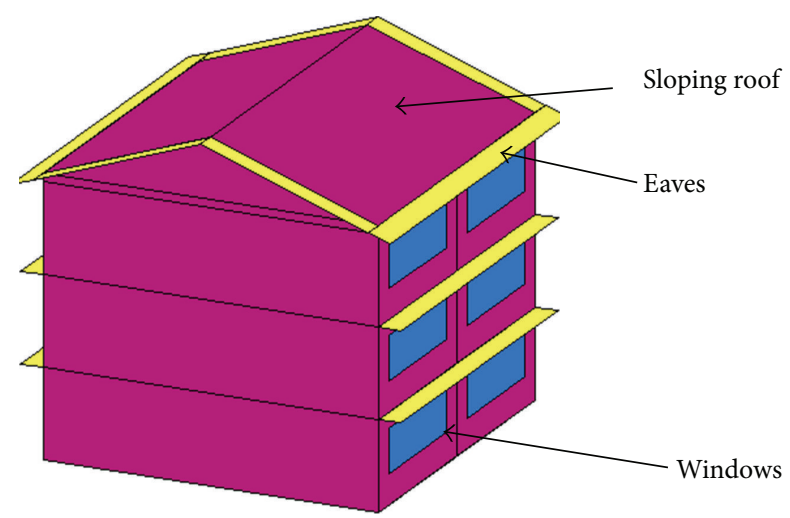

FIGURE 8: Case SR: building with a sloping roof and a flat ceiling.

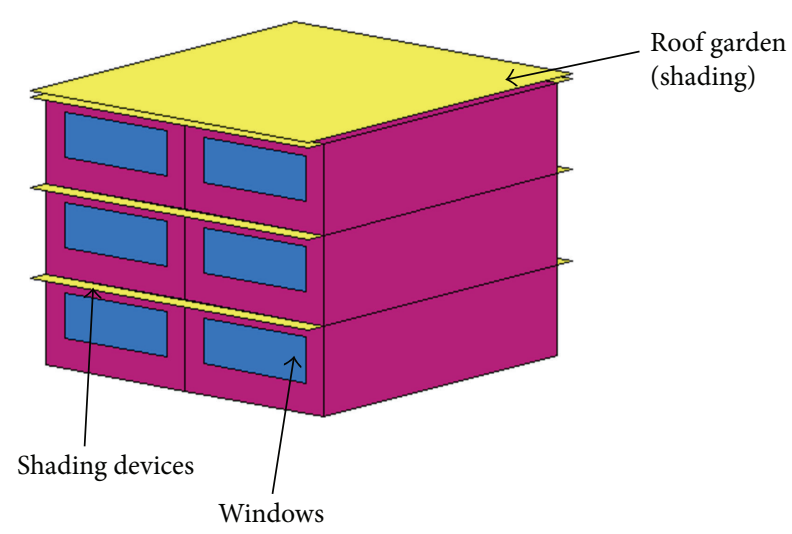

FIGURE 9: Case GR: building with a $125 \mathrm{~mm}$ thick slab and a green roof.

temperature [22]. The other possible passive features such as the effects of courtyards [23] were not considered because such features may not be common features unlike the features stated above.

It was considered that there was a $125 \mathrm{~mm}$ thick reinforcement concrete slab used on the top floor in the three-story building with a turf roof. It was also considered that there was a $25 \mathrm{~mm}$ thick soil layer over the top slab. This was taken as case GR1.

For the sloping roofs $\left(12^{\circ}\right.$ slope $)$, cement fiber sheets were included as the roof covering material. In this model, a ceiling was included and this was taken as SR1. The flat ceiling was placed $3 \mathrm{~m}$ above the 2 nd floor of the house model. The ceiling was introduced with a reflective insulation layer mounted on a $3 \mathrm{~mm}$ resistive insulation layer. These types of reflective insulations are very common at present and it has been identified that the houses that are insulated highlighted an improvement of between 1.9 and $4.5^{\circ} \mathrm{C}$ in summer in South Africa [1]. The average temperature improvement was $3.1^{\circ} \mathrm{C}$ [24]. Figures 8 and 9 illustrate the three-dimensional views of the two buildings considered.

\subsection{Comparative Analysis}

4.4.1. Cooling Loads. Sri Lanka is a country which experiences tropical climatic conditions and in low altitude the neutral temperature can be $26^{\circ} \mathrm{C}$ [25]. The range of indoor average temperatures could be 25 to $27^{\circ} \mathrm{C}$ in an air-conditioned building. Thus, considering indoor average temperature to be 25 to $27^{\circ} \mathrm{C}$ would be justifiable [1]. DEROB-LTH is capable of finding the sensible component of the air conditioning load due to solar radiation and outdoor environment. Using DEROB-LTH the cooling loads required to obtain the comfortable conditions were calculated. The climate data (average hourly temperature) of Colombo were used for the cooling load calculations.

4.4.2. Different Cases Considered. For the analysis of cooling loads, different cases (mentioned below) were considered. For each case the cooling load required to keep the temperature within comfortable limits was calculated from DEROB-LTH. These cooling loads were used to carry out the life cycle cost analysis later. The different cases considered are stated in the following: suffixes 1,2 , and 3 are used to indicate the different cases.

Case GR1: turf roof slab with $25 \mathrm{~mm}$ thick soil layer. Case GR2: turf roof slab with $50 \mathrm{~mm}$ thick soil layer. Case GR3: turf roof slab with $75 \mathrm{~mm}$ thick soil layer. Case SR1: sloping roof with reflective insulation mounted on $3 \mathrm{~mm}$ resistive insulation layer.

Case SR2: Sloping roof with reflective insulation mounted on $25 \mathrm{~mm}$ resistive insulation layer.

For DEROB-LTH analysis, the maximum possible indoor temperature was considered as 25,26 , or $27^{\circ} \mathrm{C}$. Therefore, in each case, the house was considered to be cooled to the above temperatures. They were taken as 3 options mentioned below.

Option 1: indoor temperature at $25^{\circ} \mathrm{C}$.

Option 2: indoor temperature at $26^{\circ} \mathrm{C}$.

Option 3: indoor temperature at $27^{\circ} \mathrm{C}$.

4.4.3. Effects of Grass Cover on Air Conditioning. The top floor room temperature in a three-story building is highly influenced by the roof above. The topmost floor is highly influenced by the heat transferred through the roof. Especially in air conditioning, cooling load will vary with the performance of the roof. This effect could be negligible in sheltered lower floors [1]. In the computer simulation models, air conditioning was included in comparing Cases GR1-GR3, SR1, and SR2. The cooling loads that were obtained for each case under options 1 and 3 are presented in Figures 10 and 11, respectively. They clearly demonstrate that the turf roof can perform exceptionally better than others with respect to the heat transfer through the roof.

Benefits of the turf roof slabs were clearly established in the above graphs. The sloping roofs were inefficient compared to the turf roof slabs. In option 1, higher cooling loads were obtained in case SR and the cooling loads were significantly 
TABLE 1: Capital cost of cases GR and SR with land regaining factors.

\begin{tabular}{lccc}
\hline \multirow{2}{*}{ Option } & Initial capital cost (USD) & \multicolumn{2}{c}{$\begin{array}{c}\text { Initial capital cost when the gain is deducted (USD) } \\
\text { Land prices USD 80 per m }\end{array}$} \\
\hline GR1 & 86 & Land prices USD 40 per m ${ }^{2}$ & 6 \\
GR2 & 89 & 46 & 9 \\
GR3 & 92 & 59 & 12 \\
SR1 & 41.6 & 41.6 & 41.6 \\
SR2 & 45.8 & 45.8 & 45.8 \\
\hline
\end{tabular}

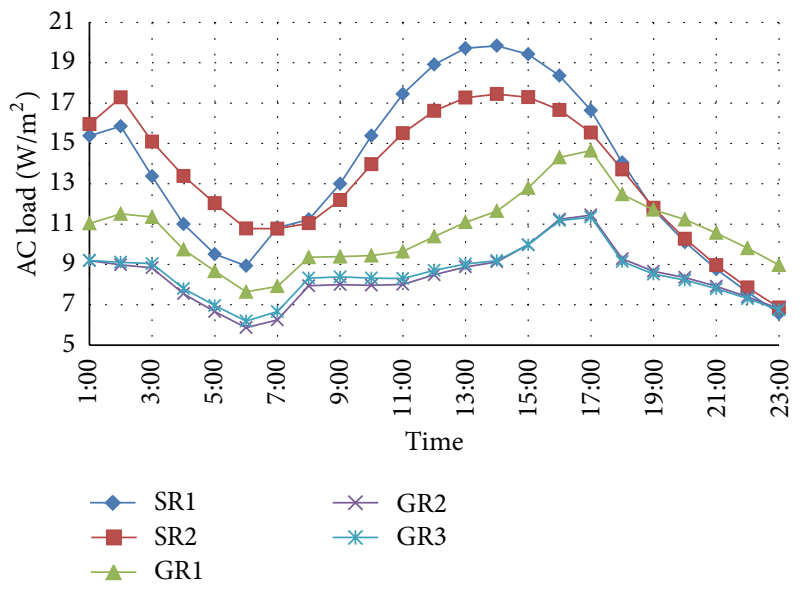

Figure 10: Cooling load for SR1, SR2, GR1, GR2, and GR3 with option $1\left(25^{\circ} \mathrm{C}\right)$.

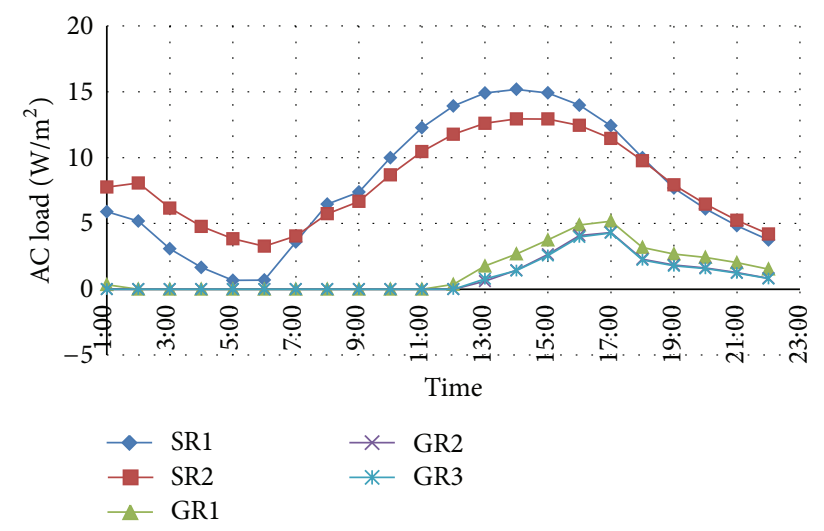

FIGURE 11: Cooling load for SR1, SR2, GR1, GR2, and GR3 with option $3\left(27^{\circ} \mathrm{C}\right)$.

lower in case GR. In case SR, a higher cooling load was required for the $3 \mathrm{~mm}$ insulation (case SR1) than $25 \mathrm{~mm}$ insulation (case SR2). However, case SR2 required a higher cooling load compared to the turf roof slabs (case GR). When considering the case GR, almost the same air conditioning loads were required in cases GR2 and GR3. When comparing GR1 and GR2 in option 1, it was noted that the difference in cooling load was significant but in option 3, a marginal difference was obtained. However, it was found that GR1 did not provide a healthy grass cover due to the limited soil thickness. The performance of GR2 and GR3 was almost the same. However, the higher the soil thickness, the higher the initial cost would be, since it would increase the load on the structure and hence the structural capacity of the structure should also be increased. Considering the results, GR2, the turf roof slab with $50 \mathrm{~mm}$ soil layer can be selected as the best to fit for a turf roof slab.

4.5. Influence on Life Cycle Costs. Due to the higher temperatures, air conditioning is frequently used in tropical countries, mainly in cities. The air conditioning loads required for these places should be minimized as much as possible to mitigate a future energy crisis.

Frequently, higher capital costs are associated with buildings in cities. However, it is more realistic to take the maintenance and services costs also into account. This warrants the life cycle cost approach. It can be illustrated as follows.

The National Institute of Standards and Technology (NIST) [24] defines life cycle cost (LCC) as "the total discounted dollar cost of owning, operating, maintaining, and disposing of a building or a building system" over a period of time. Life cycle cost analysis (LCCA) is an economic evaluation technique that determines the total cost of owning and operating a facility over a period of time.

When life cycle cost is assessed, it is possible to encounter occasions on which capital cost is high due to the low net present value of operational costs. So situations with high capital costs are also being considered in life cycle cost analysis.

When it comes to the life cycle performance of building, several other factors have also to be taken into account. For example, green roofs have the possibility of land recovery because the lost land can be regained by a roof garden. Furthermore, there are some other benefits of roof gardens such as the ability to act as cyclone resistance, add aesthetic value to the environment, and the involvement of low maintenance cost. These factors can also relate to the real performance of buildings. The land value in cities and suburbs is increasing with the demand for lands as a result of urbanization. Halwatura and Jayasinghe [1] report that the land prices in cities are in the range of USD 1000 to USD 2000 per perch. It is also noted that the prices are rising with the increasing demand for lands in suburbs. Considering the above factors, the initial costs for different cases in the models discussed in the computer simulation phase were calculated and they are presented in Table 1. 


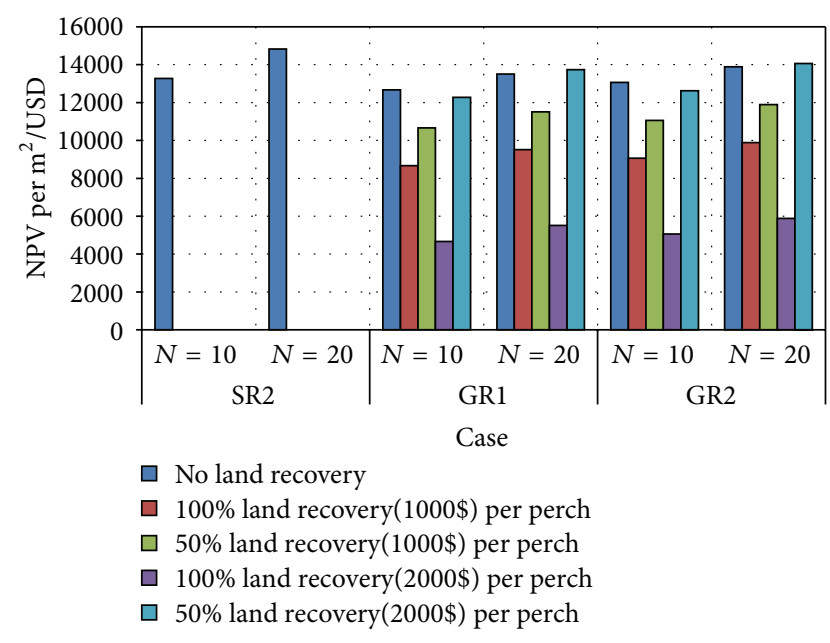

FIGURE 12: Net present values for different considerations when the discount rate is $8 \%$.

It should also be noted that the life cycle cost and service life may influence the value of land, material cost, construction methods, or other similar factors. The service life of a house with various roofing systems cannot be predicted due to environmental factors, construction techniques, and weather conditions. However, as a norm, replacement of roofing materials would be at an interval of 20 years for lightweight flat roofs [26]. For the calculations, 10- and 20year times per period were taken without considering the material used.

Discount rate is another uncertain factor in the analysis. Most of the countries have undergone negative economic fluctuations recently. The inflation rate based on GDP in Sri Lanka implicit deflator indicated 6.7\% for the year 2011 against 2010 and demonstrated a slight increase compared to the inflation rate of $6.2 \%$ recorded for the year 2010 [27]. This is the current scenario in Sri Lanka; however, this value reached $22.6 \%$ in the year 2008. Even though Sri Lanka shows lower value, many countries in the South Asian region still show a high values and many of those countries have recorded more $10 \%$ of inflation for 2011 . However, most of the other countries still have inflation rates less than $5 \%[26,27]$. Therefore, considering all the above facts, 8,10 , and $12 \%$ were selected as the discount rates for the analysis.

One criticism with regard to green roof concept could be that the land regained with a roof slab is not $100 \%$. However, as Halwatura and Jayasinghe [1] worked out, it could be presented as $50 \%$ and $100 \%$, permitting any interpolation where necessary. The net present value for each case is depicted in Figures 12, 13, and 14 at discount rates of 8, 10, and $12 \%$, respectively.

Figures 12, 13, and 14 highlight that the net present value (NPV) is higher for the houses with traditional roofs. In houses with traditional roofs, the land lost due to the house is not regained. So the NPV is higher for the houses with a sloping roof. However, in the buildings with turf roof slabs or green roofs, the value of land is regained by the roof top garden.

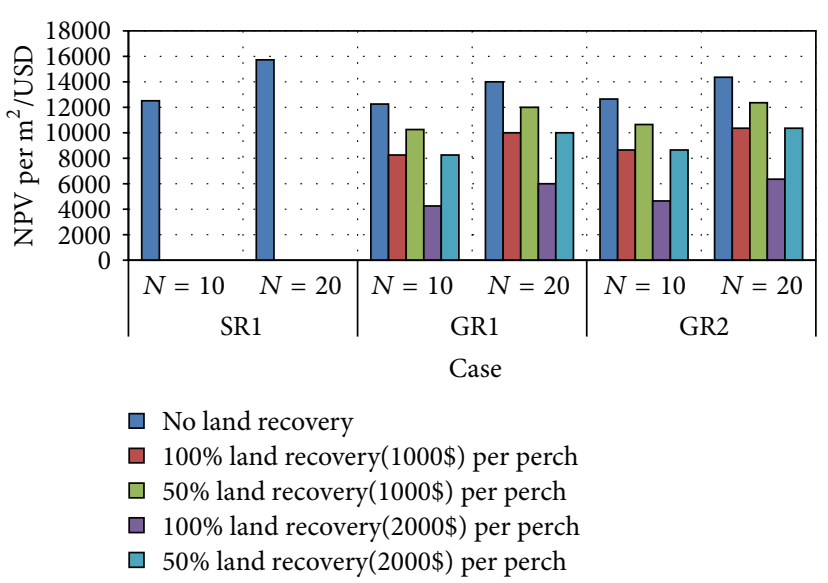

FIGURE 13: Net present values for different considerations when the discount rate is $10 \%$.

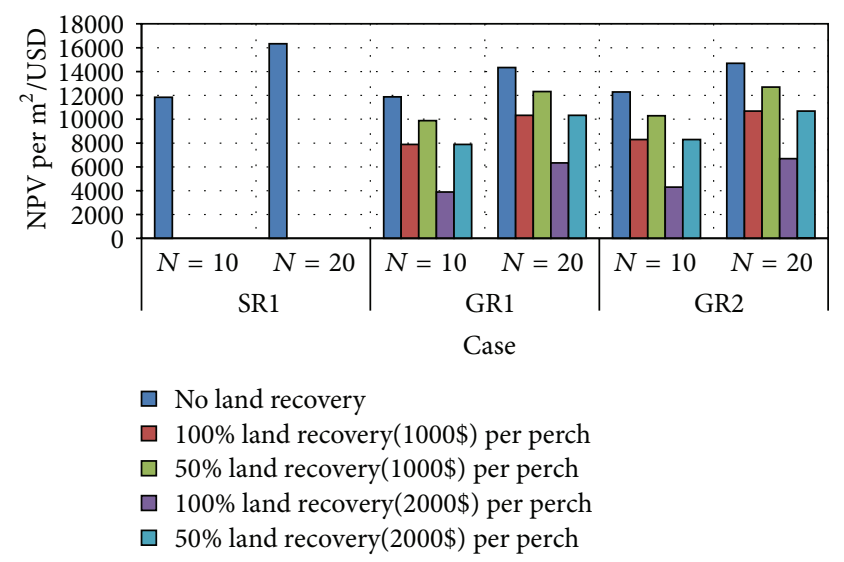

FIGURE 14: Net present values for different considerations when the discount rate is $12 \%$.

It is possible to highlight that the NPV of a green roof with $50 \%$ land recovery in 20 years exceeds the NPV of a sloping roof at ten years. The NPV with $100 \%$ land recovery for a green roof of 20 years was also fairly close to the NPV values of a sloping roof in 20-year times. This could be considered a great advantage in green roof or turf roof slabs.

\section{Conclusion}

The turf roof slabs are one of the most attractive trends in house designs in modern days. It provides a number of benefits than a house with conventional roofing. The present study highlights that green roofs of buildings have the potential to protect occupants from the high temperature conditions that prevail in tropical countries. It also highlights that green roofs can be environmental friendly since those can reduce the cooling load necessary to air condition the buildings.

The capital cost of a building does not reflect the real value of the building. Sometimes, the building with higher capital cost can be the best in life cycle cost terms. This study highlights that the capital cost of a conventional building is lower than a building with a turf roof slab; however, in terms 
TABLE 2

\begin{tabular}{lc}
\hline Materials & Conductivity $(\mathrm{W} / \mathrm{m} \mathrm{k})$ \\
\hline Concrete & 1.7 \\
\hline
\end{tabular}

The above parameters have been obtained from [22].

TABLE 3: Surface resistances.

\begin{tabular}{lll}
\hline Ceiling downwards & $R_{\mathrm{si}}$ & 0.14 \\
Roofs & $R_{\mathrm{so}}$ & 0.04 \\
\hline
\end{tabular}

of life cycle cost, a building with turf roof is more efficient. The ability to recover the lost land space is the greatest advantage of turf roof slabs.

Considering the conditions that prevail in Sri Lanka, roof top vegetation is a beneficial solution for upcoming environmental and social issues related to urbanization. However, it can be argued that the capital cost for a green roof is much higher than for a conventional roof; however, if life cycle cost is considered, buildings with roof slabs are more beneficial because green roofs save electrical costs for air conditioning, give additional exquisiteness to the building, and recover the land lost.

The other benefits provided by green roofs include reduction of the urban heat island effect, reduction of glare from the roof, decreasing of energy costs, improvement in air quality by reducing $\mathrm{CO}_{2}$ levels, increasing of oxygen output, filtering and binding of airborne dust and other particles, increasing green space, enhancing of property value, reduction of noise, and restoration of biodiversity.

\section{Appendix}

See Tables 2 and 3.

Calculation of " $U$ " values

(i) For Case 1, without soil cover,

$125 \mathrm{~mm}$ thick slab,

$$
R_{\text {body }}=\frac{0.125}{1.7}=0.07 \frac{\mathrm{m}^{2} \mathrm{~K}}{\mathrm{~W}},
$$

total resistance,

$$
\begin{aligned}
R_{\text {total }} & =R_{\mathrm{si}}+R_{\text {body }}+R_{\mathrm{so}} \\
& =0.140+0.07+0.040 \\
& =0.254 \mathrm{~m}^{2} \mathrm{~K} / \mathrm{W} \\
U & \text { value }=3.94 \frac{\mathrm{W}}{\mathrm{m}^{2} \mathrm{~K}} .
\end{aligned}
$$

(ii) For models with soil cover,

$$
\begin{aligned}
& \text { total resistance } \\
& \begin{aligned}
R_{\text {total }} & =R_{\mathrm{si}}+R_{\text {body }}+R_{\mathrm{so}} \\
& =0.140+0.07=0.21 \mathrm{~m}^{2} \mathrm{~K} / \mathrm{W}
\end{aligned} \\
& U \text { value }=4.68 \mathrm{~W} / \mathrm{m}^{2} \mathrm{~K} .
\end{aligned}
$$

\section{References}

[1] R. U. Halwatura and M. T. R. Jayasinghe, "Influence of insulated roof slabs on air conditioned spaces in tropical climatic conditions-a life cycle cost approach," Energy and Buildings, vol. 41, no. 6, pp. 678-686, 2009.

[2] S. N. Wijerathne and R. U. Halwatura, "Amplification of comfort and the air quality with green roof in cities," in Proceedings of the International Conference Structural Engineering, Construction and Management, Moratuwa, Sri Lanka, December 2011.

[3] S. N. Wijerathne and R. U. Halwatura, "The impact of green roofs on urban heat island effect," in Proceedings of the International Conference on Building Resilience (ICBR '11), Moratuwa, Sri Lanka, July 2011.

[4] I. Jaffal, S. E. Ouldboukhitine, and R. Belarbi, "A comprehensive study of the impact of green roofs on building energy performance," Renewable Energy, vol. 43, pp. 157-164, 2012.

[5] E. Eumorfopoulou and D. Aravantinos, "The contribution of a planted roof to the thermal protection of buildings in Greece," Energy and Buildings, vol. 27, no. 1, pp. 29-36, 1998.

[6] T. Takakura, S. Kitade, and E. Goto, "Cooling effect of greenery cover over a building," Energy and Buildings, vol. 31, no. 1, pp. $1-6,2000$.

[7] D. Townshend, "Study on green roof application in Hong Kong," Architectural services department, 2007.

[8] World Urbanization Prospects, the 2011 Revision, Department of Economic and Social Affairs, United Nation, New York, NY, USA, 2012.

[9] T. A. Obaid, State of World Population 2007: Unleashing the Potential of Urban Growth, UNFPA, 2007.

[10] G. Anker, Urbanization Overspeed in Tropical Africa 1970-2000, INUPRESS, Geneva, Switzerland, 1986.

[11] M. Duneier, Ethnography, the Ecological Fallacy and the 1995 Chicago Heat Wave, Princeton University and CUNY Graduate Center.

[12] S. Onmura, M. Matsumoto, and S. Hokoi, "Study on evaporative cooling effect of roof lawn gardens," Energy and Buildings, vol. 33, no. 7, pp. 653-666, 2001.

[13] R. U. Halwatura and M. T. R. Jayasinghe, "Strategies for improved micro-climates in high-density residential developments in tropical climates," Energy for Sustainable Development, vol. 11, no. 4, pp. 54-65, 2007.

[14] R. U. Halwatura and A. A. D. A.J. Perera, "Risk in the use of asbestos roofing sheets in Sri Lanka, Environmental Science and Policy," in Proceedings of the Annual Symposium, Kothalawala Defence University, Kotte, Sri Lanka, December 2009.

[15] M. T. R. Jayasinghe and C. Jayasinghe, Sustainable Design of Building, University of Moratuwa, Moratuwa, Sri Lanka, 2009.

[16] M. T. R. Jayasinghe and D. P. K. Maharachchi, "Use of reinforced brickwork for crack free load bearing construction," in Proceedings of the Research for Industry, pp. 38-51, Engineering Research Unit, University of Moratuwa, 1998.

[17] B. L. Ong, "Green plot ratio: an ecological measure for architecture and urban planning," Landscape and Urban Planning, vol. 63, no. 4, pp. 197-211, 2003.

[18] R. L. Duble, "Buffalo Grass," http://aggie-horticulture.tamu .edu/archives/parsons/turf/publications/buffalo.html.

[19] R. U. Halwatura and M. T. R. Jayasinghe, "Thermal performance of insulated roof slabs in tropical climates," Energy and Buildings, vol. 40, no. 7, pp. 1153-1160, 2008. 
[20] T. G. Theodosiou, "Summer period analysis of the performance of a planted roof as a passive cooling technique," Energy and Buildings, vol. 35, no. 9, pp. 909-917, 2003.

[21] K. Källblad, "A method to estimate the shading of solar radiation: theory and implementation in a computer program," in Proceedings of the the Sixth International BPSA Conference, pp. 595-601, Building Performance Simulation Association, 1999.

[22] C. Ratnaweera and A. G. Hestnes, "Enhanced cooling in typical Sri Lankan dwellings," Energy and Buildings, vol. 23, no. 3, pp. 183-190, 1996.

[23] A. I. Jayawardhana, Passive techniques for energy efficiency of building in Sri Lanka [M.S. thesis], Department of Civil Engineering, University of Moratuwa, Moratuwa, Sri Lanka, 2002.

[24] K. S. Fuller and S. R. Petersen, NIST Handbook 135: Life Cycle Costing Manual for the Federal Energy Management Program, U.S. Government Printing Office, Washington, DC, USA, 1996.

[25] M. T. R. Jayasinghe and R. A. Athalage, "Passive techniques for residential buildings in low altitudes of Sri Lanka," vol. 30, no. 2, pp. 18-27, 1999.

[26] R. Kumar and S. C. Kaushik, "Performance evaluation of green roof and shading for thermal protection of buildings," Building and Environment, vol. 40, no. 11, pp. 1505-1511, 2005.

[27] A. Kadirgamar, "Legitimacy and crisis in Sri Lanka," Economic and Political Weekly, vol. 47, no. 9, pp. 25-29, 2012. 

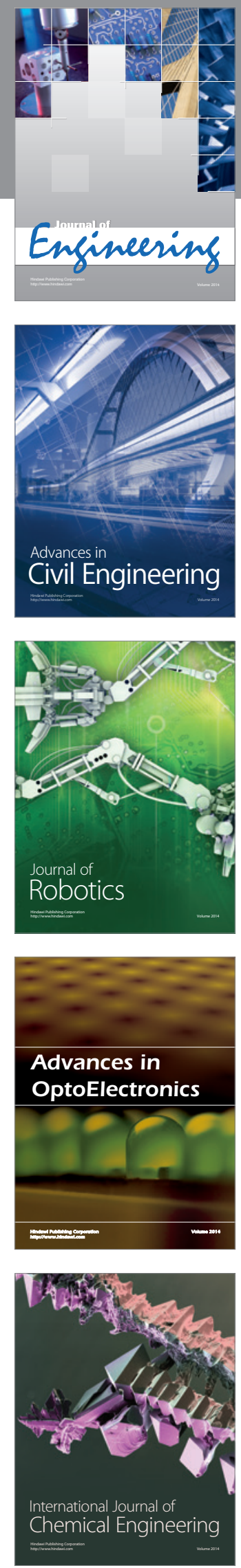

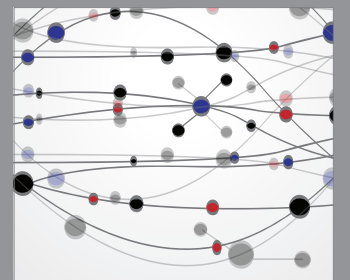

The Scientific World Journal
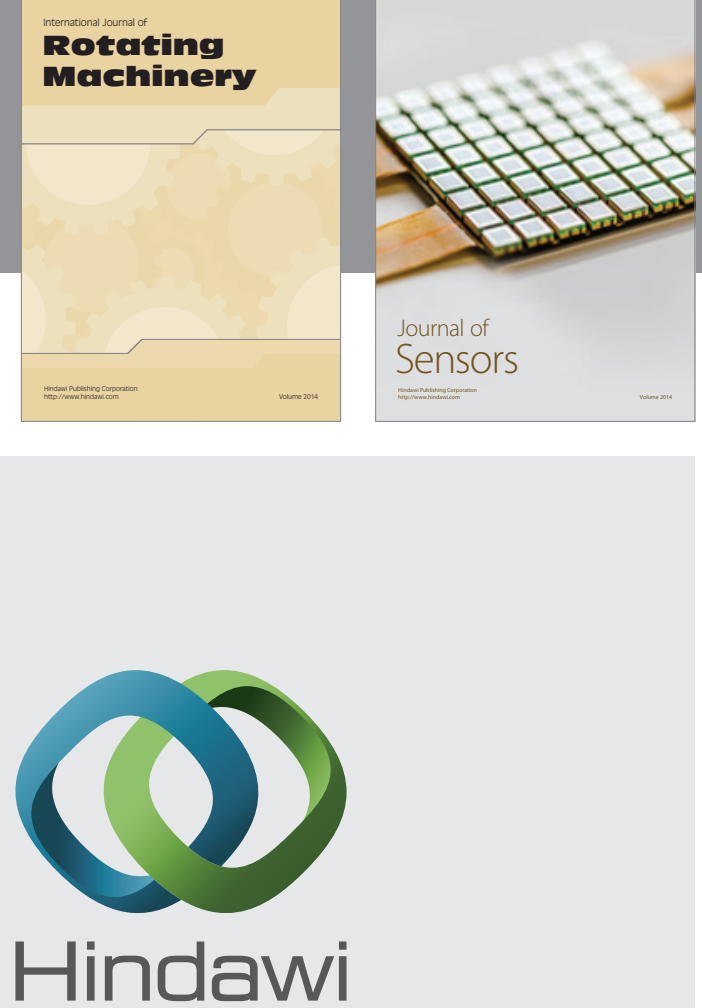

Submit your manuscripts at http://www.hindawi.com
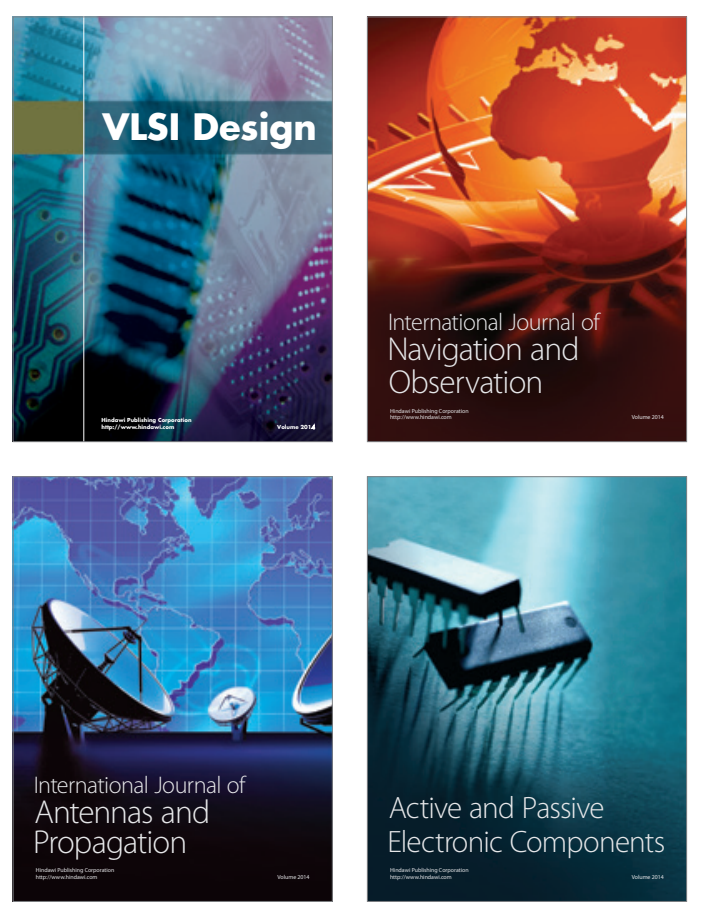
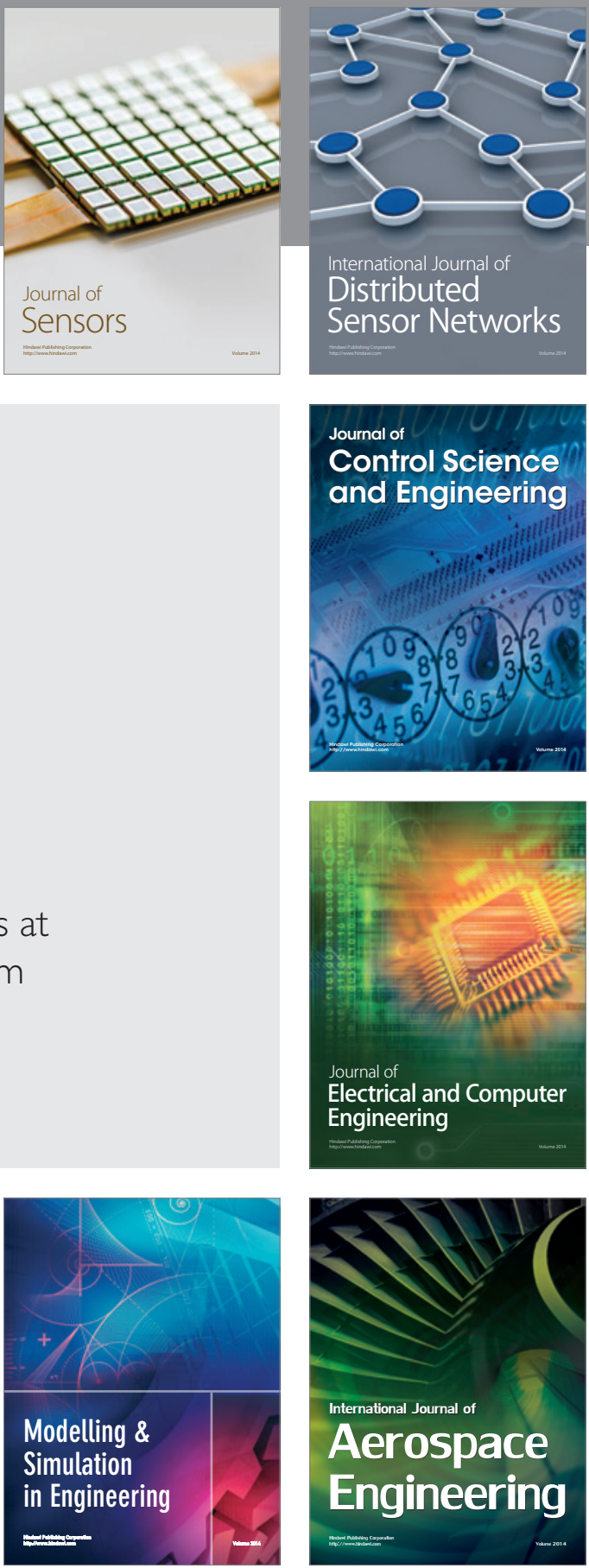

Journal of

Control Science

and Engineering
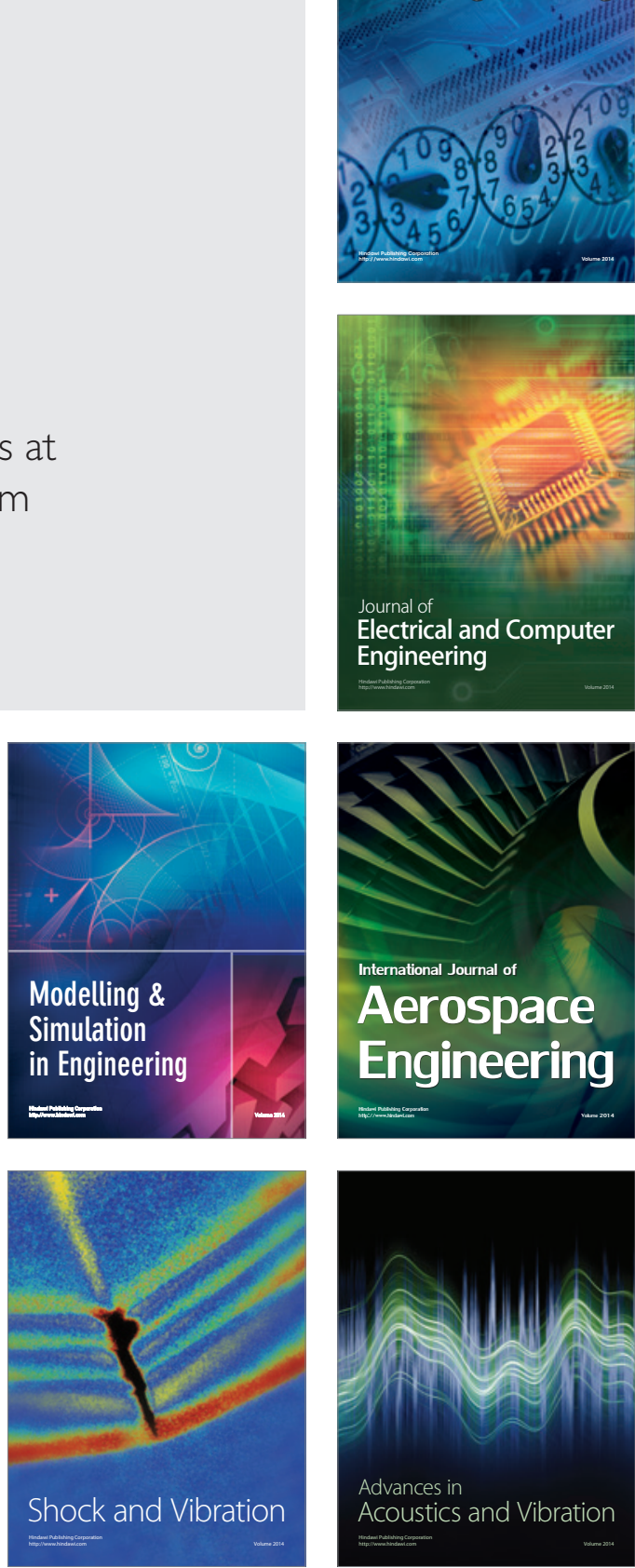